\title{
INCIDENCE OF INFECTIONS WITH PFEIFFER'S BACILLUS BEFORE, DURING, AND AFTER THE 1918 EPIDEMIC
}

\author{
By J. W. MoLEOD, A. G. RITCHIE, ANd C. A. DOTTRIDGE
}

THE observations to be recorded below are in many respects incomplete, and in view of the large number of papers which have already been written on the subject of influenza it is desirable to explain at the outset the reasons which seem to us to justify this publication. In the first place, the observations, though small in number, were made at various periods from the outset of the epidemic till 1920, and the same technique was employed throughout; whereas most publications on the subject bave referred to investigations carried out during some shorter period or with varying technique. Secondly, some of the observations relate to cases seen at the very outset of the epidemic, and it is in regard to the incidence of Pfeiffer's bacillus in the early stages of the summer epidemic of 1918 that there appears to be most diversity of opinion.

An extensive review of the bacteriology of influenza has recently been published by Fildes and McIntosh (1). These authors make out a strong case for Pfeiffer's bacillus as the cause of epidemic influenza. In developing this conclusion they summarize the published evidence for the existence of a filterpassing virus and show that it is decidedly weak. They also review the records of experimental evidence for the selective action of B. Pfeiffer toxin on the pulmonary tissues, which have rapidly accumulated in the last two years.

There is, however, no detailed comparison in their review of the incidence of Pfeiffer's bacillus during the years preceding the epidemic with that in the epidemic period.

The observations of the epidemiologists go to show that there is something like a ten-year cycle in epidemic influenza, a heavy incidence having been noted in $1869,1879,1890$, and 1898 , but not apparently between that period and the recent epidemic (Stallybrass (2)).

If Pfeiffer's bacillus is the cause of influenza, it is to be expected that the investigations recorded with regard to its incidence should show a gradual diminution of infections due to that bacillus in the years following an epidemic, and a gradual increase in infections due to it in the years immediately preceding an epidemic. We have tried to get information on these points from the literature. Unfortunately the relatively small number of investigations recorded in which Pfeiffer's bacillus has been carefully sought in the absence of influenza epidemics,
[Q. J. M., July, I922.]
A a 2 
the varying competency of the investigators, and the variety of culture media chosen are all factors which make it difficult to reach a very certain conclusion.

It is well, however, to examine carefully such findings as have been recorded and to analyse as far as possible their significance.

Fortunately Tedesko (3) has published a very extensive collection of observations relating to the incidence of infections due to Pfeiffer's bacillus between the years 1896-1906. This author points out that the incidence of infections due to that bacillus, as determined by P.M. observations and by examinations of the sputum during life, rose steadily to a maximum in the years 1899 and 1900, and then fell away rapidly till in 1905-6 there were only 5-6 P.M.'s per annum in which Pfeiffer's bacillus was found, as compared with 90 in the year 1900 .

Since these observations were made throughout with the same technique, and are therefore comparable, the conclusion may be drawn with some confidence that in the area to which they relate-the southern part of Central Europe-there was an epidemic prevalence of $B$. influenzae infections on a small scale about the beginning of this century; and further, that the incidence of infections with Pfeiffer's bacillus diminished in the following years, and had become almost negligible when the series of observations was terminated in 1906.

Table I gives a summary of the principal recorded observations on the incidence of Pfeiffer's bacillus in the period between 1900 and the first winter of the European war. The data are rather slender, but so far as they go they suggest the following ideas :

1. That in Europe the incidence of Pfeiffer infections was low throughout this period, although there were probably some localized epidemics like that recorded by Scheller (10) and nearly corresponding to the period of the suggested ten-year cycle.

2. That in America, although no epidemic with a high incidence of Pfeiffer infections is recorded, yet there appears to be, in certain areas at all events, a rather high endemic rate of infections with Pfeiffer's bacillus in ehronic bronchitis. .

3. That there seems to be little doubt that amongst children a high percentage of infections with haemoglobinophilic bacteria, whether B. Pfeiffer or not, is the rule in all conditions associated with catarrh of the respiratory tract.

4. That taking into account the rather scanty observations available on normal individuals, and those on cases of pulmonary tuberculosis, one can probably fix the percentage of carriers of Pfeiffer's bacillus in a population which has not been recently visited by an influenza epidemic, as between nil and 10 per cent.

In Table II we have summarized all records of infections with Pfeiffer's bacillus between the first winter of the war and the outbreak of the 1918 epidemic which we have been able to find. A comparison of the two tables brings out at once certain contrasts. These are: first, that a much larger number of localized epidemies of 'influenza', bronchitis, or atypical pneumonia associated with $B$. Pfeiffer infection was recorded between 1915 and 1918 than in the 
preceding years; second, that the figures for incidence of Pfeiffer's bacillus in connexion with influenza were higher in these epidemics than in any recorded in the previous ten years, except that reported by Scheller (10) at Königsberg in 1907 ; third, that the contrast between the figures before and after 1915 is not found in the American as in the European publications.

To take up now the question of incidence during the epidemic. Many bacteriologists failed to find Pfeiffer's bacillus in the early summer epidemic, but its presence in a high percentage of cases was reported in areas wide apart and by observers who were altogether independent of one another, e.g. Meunier (31) and Krumbhaar (32) in France; Matthews (33) in London: von Bergmann (34) and Dietrich (35) in Germany. The almost constant presence of B. influenzae in the early stages of the disease during the autumn epidemic is now generally admitted, and it need not therefore be further discussed.

A further contrast between the epidemic and pre-epidemic periods can be made in the incidence of Pfeiffer's bacillus amongst the healthy population. Observations of this kind do not appear to have been numerous, but they coincide pretty nearly. Thus, Pritchett and Stillman (36) found amongst 177 normal individuals, 41 per cent. carriers; Fildes $(1$ and 37$)$ found from 18 per cent. to 64 per cent. of carriers on different occasions; Cummins (38) quotes the very extensive observations made in the Medical Corps, U.S. Army: out of 2,179 persons examined 595, or 27 per cent., were found to be healthy carriers.

Lastly, there are one or two observations available giving the incidence of B. Pfeiffer in the throats of normal individuals in 1920 , i. e. after subsidence of the main epidemic. Thus Edington (39) found that the carrier rate amongst troops after the subsidence of a small localized epidemic was 6 per cent.; while Sellers and Lepage (40), examining the naso-pharynx of children with chronic naso-pharyngeal catarrh, found four carriers of $B$. influenzae amongst 101 children.

The foregoing data may therefore be summarized as follows: In so far as the records can be trusted, they lead to the general conclusions that Pfeiffer infections, after remaining infrequent for many years, were noticed in numerous localized epidemics from 1915 onwards, till during the epidemic of 1918 the great majority of the patients attacked, and also a very considerable percentage of healthy contacts, were found to be infected with Pfeiffer's bacillus; but that with the disappearance of the epidemic the incidence of Pfeiffer's bacillus in the respiratory tract of healthy individuals has notably diminished.

We can now proceed to record our own observations, and to note how far they fall into line with the above summary of the relationship of Pfeiffer's bacillus to epidemic influenza. We have unfortunately no record of the incidence of Pfeiffer infections amongst healthy individuals prior to the 1918 epidemic. In February 1917, however, one of us saw a case which very definitely supported the impression derived from the literature that there were many localized influenzal epidemics in that year. The case was seen owing to the kindness of Capt. Hoskin, of 29 C.C.S., under whose care the patient was. This officer's 
attention had been specially drawn to the fact that he was receiving cuse after case, many of them coming from one regiment, all of which presented somewhat similar features-namely, continuous fever, fine bronchitis, and nephritis : amongst these there was a very heavy mortality. The patient in question died after ten or eleven days of continuous fever associated with bronchitis, anasarca, occasional uraemic convulsions, and haematuria. At post-mortem it was found that there was a capillary bronchitis throughout both lungs, associated fwith uniformly distributed and almost confluent patches of broncho-pneumonia. There was no pleural exudate, but a number of sub-pleural petechiae, and the kidneys showed a very marked haemorrhagic nephritis. Films taken from the lung tissue showed an abundant exudate of polymorphonuclear leucocytes, and about one in every ten of these was loaded with fine Gram-negative bacilli. The lung juice inoculated copiously to ordinary agar gave very fine but numerous colonies of Pfeiffer's bacillus in pure culture. This case is interesting in two respects : first, it was in all probability one of a group of Pfeiffer infections, since the other cases had closely resembled it in their clinical features; but unfortunately the epidemic was nearly at an end when this case was seen, and opportunity for investigation of a series did not occur. Secondly, the kidney lesion, a markedly haemorrhagic nephritis, had been rare amongst the cases of so-called 'war nephritis' seen up to that time, and the tendency shown by Pfeiffer's bacillus to produce haemorrhagic lesions is well recognized; further, the intimate and dangerous relationship between influenza and nephritis has been emphasized since by Symonds (41), and in the report of the Influenza Committee to the D.G.M.S., France (42). Histological preparations from the lung showed in a marked way the infiltration of the walls of the small bronchioles with plasma cells, which has been described by Hiubschmann (43) in his careful histological study of the lungs from the cases which he examined in the influenza epidemic at Leipzig in 1915. This case can probably be taken as an example of the subacute Pfeiffer lesion and contrasted with the acute or fulminant one met in the course of the general epidemic, when the bacillus had presumably reached the zenith of its virulence.

\section{Observations on the Summer Epidemic, 1918.}

The frst cases coming under our observation in May had rather prominent gastric symptoms, and an investigation of them as possible cases of food poisoning was required. The clinical resemblance to influenza was soon obvious, however, and attempts to demonstrate $B$. influenzae were successful when the sputum of the first patient seen with a bronchial complication was examined by cultivation on human blood agar.

After a number of further investigations with various media had been made it was found that although isolation and preservation of the bacillus were difficult on human blood agar, yet with rabbit's blood agar it was easy to obtain profuse growths. This medium was therefore adopted as appropriate for an investigation of a series of cases to determine the incidence of infection with 
Pfeiffer's bacillus. (It is notable that those investigators who have used blood other than human for preparing their media have usually recorded a high percentage of positive findings, Tables I and II. Little and Williams (44) recommend a rabbit's blood medium, and it is certainly as good as the altered blood media.)

A series of twelve cases was examined, and each was carefully charted and recorded. The clinical description of our cases written at the time when they were under observation ran as follows: The onset was sudden in all cases, and at the commencement there was constantly a complaint of frontal headache and muscular pains. In two only of the twelve cases there were diarrhoea and vomiting at the outset, which ceased in a few hours. The pains and headache diminished as the pyrexia fell. Coryza and pharyngitis were present in all, but only four showed bronchitis, and in one only amongst these was it severe. The fauces were injected and the uvula reddened and oedematous, with a covering of stringy mucus, but no enlargement of the tonsils was observed. There was no definite evidence of cardiac enfeeblement or of post-influenzal depression when those patients got about again after a few days. The temperature rose sharply at the outset, but had returned to normal by the third day in all cases except those in which the condition of the patient was complicated by a second lesion, e. g. a chronic urethral discharge; in these cases the subsidence of the temperature was more gradual.

Pfeiffer's bacillus was detected in eight of these cases (66 per cent.), and as this examination was often made when the patient's temperature had already returned to normal, the percentage infected was obviously high.

The clinical record of these cases has been given in detail because it seems probable that the statement so often made, that epidemics of influenza occur in which $B$. . Pfeiffer is not found, depends upon the fact that clinical differentiations of catarrhs of the upper respiratory passages have not been carefully enough worked out in connexion with the bacteriological findings. In this connexion the findings of Edington (39) aro very instructive. He examined four separate small epidemics amongst troops in 1920 ; in three of these B. Pfeiffer was found almost in every case, but in the fourth it was absent; it was then found on closer examination that the clinical histories in the cases from the fourth epidemic differed in some respects from those recorded in the other three. The two chief features by which Edington distinguished clinically between the true and spurious influenza cases which he observed were the presence of eye symptoms and the slight involvement of the throat in the latter. In both these respects, therefore, our cases correspond with those in which Edington found Pfeiffer's bacillus, i. e. they had no eye symptoms, but rather marked involvement of the throat.

\section{Observations on the Carrier Rate at the Height of the Early Summer Epidemic.}

Two dozen chronic venereal cases, otherwise in ordinary health, were examined by preparation of cultures with swabs taken from the naso-pharynx. Eight of these, 
i. e. 33 per cent., were found positive. The number of cases, of course, is too small to yield an accurate figure, but it corresponds pretty closely with the observations of others with regard to the carrier rate during the epidemic period.

\section{Period of the Autumn Epidemic.}

For a variety of reasons we were prevented from making any observations on the percentage incidence of infections by Pfeiffer's bacillus at this period. One post-mortem observation seems to us to be worth noting.

The patient, a Canadian officer, went to sleep without special complaint one night; in the morning he was found unconscious in his bed, and as the troops had just crossed the frontier into Germany it was suspected that there had been foul play, and that he had been poisoned with coal-gas. He died shortly after reaching hospital at Spa, and within twenty-four hours of the time when he was found unconscious. A post-mortem examination revealed the pulmonary lesion characteristic of fulminant influenza, i. e. haemorrhagic oedema of the lungs with, here and there, little yellow-white specks. Cultures from the cut surface of the lungs showed B. Pfeiffer in abundant and almost pure culture. Owing to the fact that the laboratory was constantly moving at this time no attempt to prepare histological sections was made, but the lesion corresponds to that of acute influenza as described by Tytler, Jones, and Dobbin (45), and also by Menétrier (46). The lesion described by Menétrier is identical with that described above; it occurred in a rather less fulminant although very rapidly fatal case. B. influenzue was recovered in pure culture, and Menétrier, although he does not accept the conclusion that Pfeiffer's bacillus is the cause of influenza, maintains that the lesion described is that of Pfeiffer's bacillus. Tytler, Jones, and Dobbin state that diffuse haemorrhage with oedema was characteristic of the most acute cases, and, apart from staphylococci, which were found as often, but in smaller numbers, $B$. Pfeiffer was much more common than any other bacterium in these cases.

It is very difficult to sustain the theory that $B$. Pfeiffer is merely a secondary invader in such a case, since you have associated : first, the type of lesion recognized as characteristic of Pfeiffer's bacillus ; second, the bacillus itself predominant and abundant in the lung; third, an invasion of the tissues, as rapidly followed by death as is known in any disease.

It may, of course, be maintained that this case only illustrates the fact that during an influenza epidemic, due to some virus as yet unrecognized, the virulence of all bacteria commonly found in the respiratory tract is raised. This is not strictly accurate, however, for lesions of the kind described are rarely, if ever, met, except during epidemics of influenza, whereas the pneumococcal and streptococcal lesions met in influenza epidemics are commonly seen in non-epidemic periods. 
Observations on Cases showing Pulmonary Complications in March, 1919. The Third Epidemic Wave.

The investigations were unfortunately cut short, but, of 15 sputa examined, 12, i. e. 80 per cent., showed B. Pfeiffer in culture, and in more than half of these it was very abundant and the predominant bacterium. A number of post-mortem observations were also made at this time; no fulminant eases such as had occurred in the autumn epidemic were seen in this series. The patients died after 7-12 days' illness, and suppurative pneumococeal, streptococeal, and staphylococcal lesions predominated, although here and there an influenzal broncho-pneumonia, with $B$. Pfeiffer predominant, was observed.

If Hübschmann's (43) conclusions are sound, the deaths in this third epidemic wave were mainly due to the facilitation of invasion of the lung by varied microorganisms, which results from previous Pfeiffer lesions. He considers that a number of the bronchioles are left dilated after a Pfeiffer infection because of weakening of their muscular coat, and that, owing to a tendency to stagnation in such bronchioles, the natural mechanism of the lung for resisting infection is crippled.

\section{Observations on Healthy Individuals, March, 1920.}

Forty-seven venereal out-patients were examined by cultivation of swabs taken from the naso-pharynx. Four gave positive results, i. e. about 8 per cent.

This percentage of carriers of Pfeiffer's bacillus amongst the population a year after the epidemic corresponds to that of Edington, and is also within the range of such observations as exist with regard to the carrier rate in previous inter-epidemic periods. It contrasts very strikingly with the figures obtained in the epidemic period however.

\section{Swmmary and Conclusions.}

The general trend of the literature dealing with the frequence of infections with Pfeiffer's bacillus before, during, and after influenza epidemies is to strengthen the evidence for regarding that bacillus as the cause of influenza. We appear to be dealing with a bacillus relatively rare in the periods remote from epidemics, finding opportunity of exalting its virulence by frequent passage in numerous localized epidemics in the years immediately preceding a major epidemic, and then finally reaching that high degree of infectivity which enables it to affect a very large proportion of the community. It then rapidly increases its virulence, till at the height of the epidemic it becomes capable of producing a fulminating illness with a characteristic lesion rarely seen at other times. Young children, however, seem to stand in a different relationship from adults to infections with haemoglobinophilic bacteria, as such infections appear to be relatively frequent amongst them in non-epidemic periods. How far these haemoglobinophilic 
bacteria found in the respiratory tract of young children correspond to Pfeiffer's bacillus it is difficult to say. The observations of Wollstein (47) and Scheller (10) show that differentiation within the group is by no means an easy matter. However that may be, the peculiar susceptibility of infants to infections with this class of bacteria is shown by the fact that so many of the recorded cases of influenzal meningitis have been in very young ehildren (Ritchis (48)). And it seems not unlikely that the relatively greater susceptibility of young children to broncho-pneumonia is also related to their greater sensitiveness to infections by this group of bacteria.

Various explanations of the periodicity of influenza epidemics have been put forward. This periodicity may, of course, be due to certain cycles in the evolution of the bacteria; another explanation, however, which is frequently suggested is that an attack of the disease is followed by a long period of immunity. There are considerable difficulties in accepting the second explanation-a third is suggested by the observations of Richter (49). He showed that examination of records of disease and weather in all countries in which they had been kept over considerable periods demonstrated the coincidence of high incidence of pulmonary disease with prolonged periods of anticyclonic conditions, the atmosphere being apparently more irritating to the lungs during these periods. On this basis the periodicity is in the weather, and at more or less regular intervals the conditions recur in which the tendency to bronchial irritation is greatest. A very natural consequence of this would be that a bacterium like Pfeiffer's bacillus, which apparently tends to persist in the adult human body chiefly as an agent of chronic bronchitis, would find a special opportunity for extended propagation, i. e. for exaltation of virulence by passage.

All the above conclusions can only be tentative on account of the restricted scope of the investigations which have been made on the incidence of infections with Pfeiffer's bacillus during inter-epidemic periods, and it is emphatically required that the gaps in our information should now be made good in several respects. Amongst these are: first, that more careful and systematic investigations should be made in order to correlate clinical symptoms and bacteriological findings in acute catarrhs of the upper respiratory tract, with a view to their differentiation; second, that the percentage of carriers of the $B$. influenzae amongst the bealthy population should be determined yearly in various places; third, that more data should be obtained as to the percentage of Pfeiffer's infections in various diseases of the respiratory tract, in order to find whether the high percentage of such infections recorded in pulmonary disease by one or two American investigators is usual or not. 


\section{REFERENCES.}

1. Fildes and McIntosh, Brit. Journ. Exp. Path., 1920, i. 119.

2. Stallybrass, Lancet, Lond., 1920, i. 372.

3. Tedesko, Centr. f. Bakt. u. Parasit., Jena, Abt. I, Orig., 1907, xliii. 322, 432, and 548.

4. Ritchie, Journ. Puth. \& Bact., Edinb., 1901, vii. 1.

5. (1) Jones, Amer. Joum. Med. Sci., 1911, cxli. 267.

(2) Madison, Journ. Amer. Med. Assoc., 1910, lv, 477.

6. Hastings and Niles, Joum. Exp. Med., New York, 1911, xiii. 638.

7. Walb, Deutsch. med. Wochensch., Leipz., 1913, xxxix. ii. 2394.

8. Jundell, (quoted) Jou'n. Amer. Med. Assoc., 1912, lviii. 1488.

9. Wollstein, Journ, Exper. Med., New York, 1906, viii. 681.

10. Scheller, Deutsch. med. Wochensch., Leipz., 1912, xxxviii. ii. 1825.

11. Wilson and Miller, Lancet, Lond., 1909, ii. 1661.

12. Holt, (quoted) Journ. Amer. Med. Assoc., 1914, lxiii. 1979.

13. Madison, ibid., 1910, lv. 477.

14. Davis, ibid., 1915, lxiv, 1814.

15. Luetscher, Archives Int. Med., Chicago, 1915, xvi. 657.

16. Hamblet, Barnes, and Lake, ibid., 1916, xviii. 313.

17. Wilson, Lancet, Lond., 1919, ii. 607.

18. Hunt and Rankin, ibid., 1915, ii. 1133.

19. Hübschmann, Münch. meḋ. Wochensch., 1915, lxii. 1073.

20. Paltauf and Petruschky (quoted by Hübschmann).

21. Arneth, Zeits.f. klin. Med., Berlin, 1916, lxxxii. 27.

22. Williams and Burdick, Med. Rec., New York, 1916, lxxxix. 876.

23. Scholz, Med. Klinik, Berlin, 1916, xii. 1065.

24. Nammack, Med. Rec., New York, 1916, lxxxix. 368.

25. Mathers, Journ. Amer. Med. Assoc., 1916, lxvi. 30 ; ibid., 1917, lxviii. 678; Joum. Infect. Dis., Chicago, 1917, xxi. 1.

26. Moody and Capps, Journ. Amer. Med. Assoc., 1916, lxvi. 1696.

27. Dunn, J. S., Contribution to discussion on Influenza at Meeting of Pathological Society of Great Britain and Ireland, Lond., March, 1920.

28. Hammond, Rolland, and Shore, Lancet, Lond., 1917, ii. 41.

29. Abrahams, Hallows, Eyre, and French, ibid., 1917, ii. 377.

30. Robertson, Journ. Amer. Med. Assoc., 1918, 1xx. 1533.

31. Meunier, Bull. de l'Acad. de Méd., Paris, 1919, lxxxi. 51.

32. Krumbhaar, Lancet, Lond, 1918, ii. 123.

33. Matthews, ibid., 1918, ii. 104.

34. von Bergmann, (quoted) Bull. de l'Inst. Past., Paris, 1918, xvi. 604.

35. Dietrich, (quoted) ibid., 743 .

36. Pritchett and Stillman, Joum. Exp. Med., New York, 1919, xxix. 259.

37. Fildes, Baker, and Thompson, Jancet, Lond., 1918, ii. 697.

38. Cummins, Med. Res. Com. Special Report Series, Lond., 1919, No. 36, 16.

39. Edington, Lancet, Lond., 1920, ii. 340.

40. Sellars and Lapage, Proc. Roy. Soc. Med., Sect. Dis. in Children, Lond., 1920, xiii. 143.

41. Symonds, Lancet, Lond., 1918, ii. 664.

42. Report of the Influenza Committee of the Advisory Board to the D.G.M.S., France, Brit. Med. Joum., 1918, ii. 505.

43. Hübschmann, Ziegler's Beitrage z. palh. Anat., Jena, 1917, lxiii. 202.

44. Little and Williams, Med. Res. Com. Special Report Series, Lond., 1919, No. 36, 93.

45. Tytler, Jones, and Dobbin, ibid., 77.

46. Menétrier, Bull. de l'Acad. de Méd., Paris, 1919, lxxxi. 99.

47. Wollstein, Joum. Exp. Med., New York, 1915, xxii. 445.

48. Ritchie, Joum. Path. \& Bact., Edinb., 1910, xiv. 615.

49. Richter, Joum. Amer: Med. Assoc., 1911, lvii. 1964. 


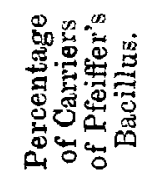

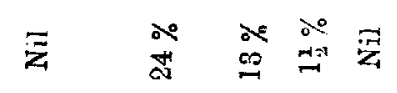

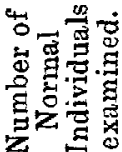
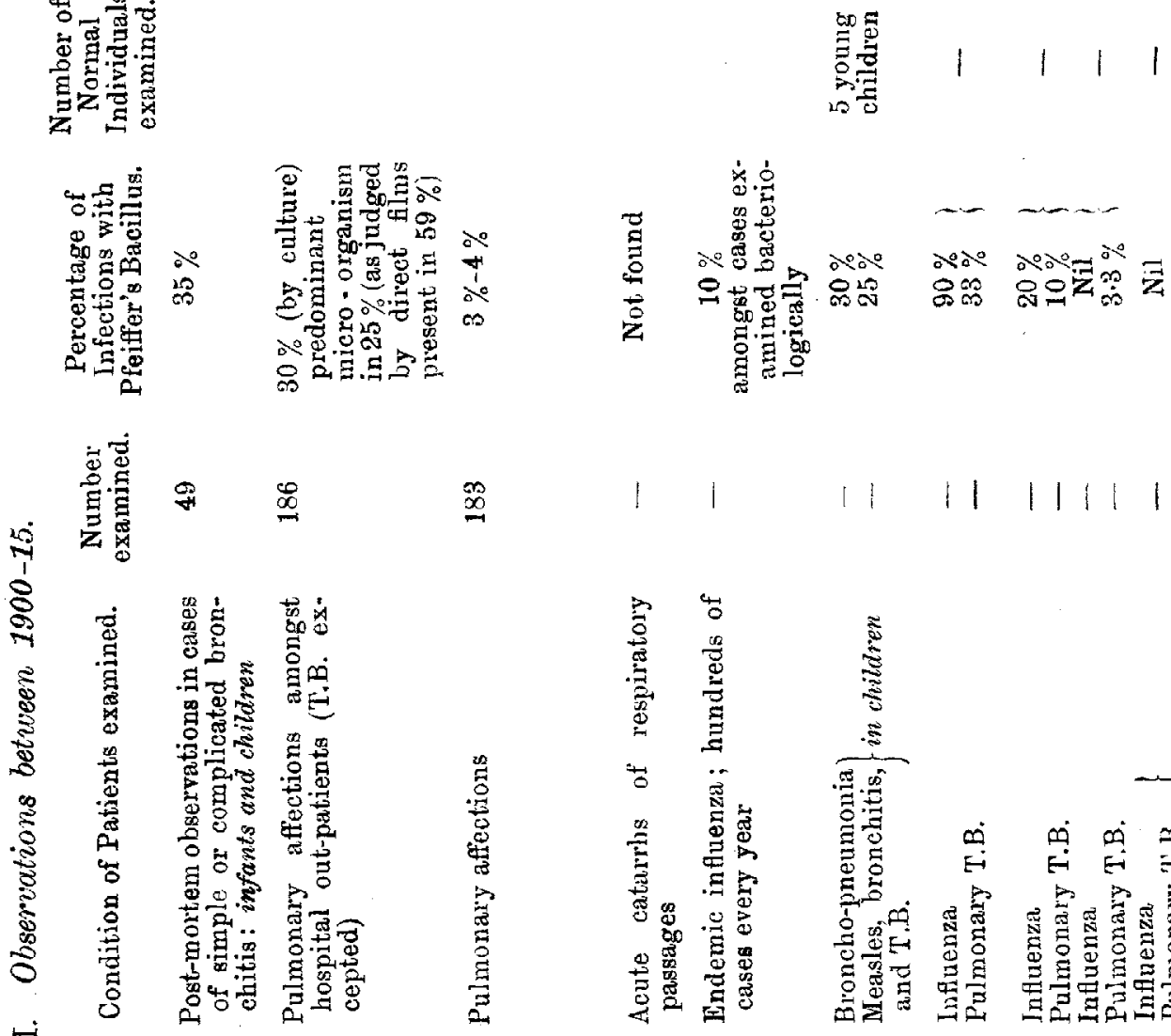

$\stackrel{\circledast 2}{\otimes}$

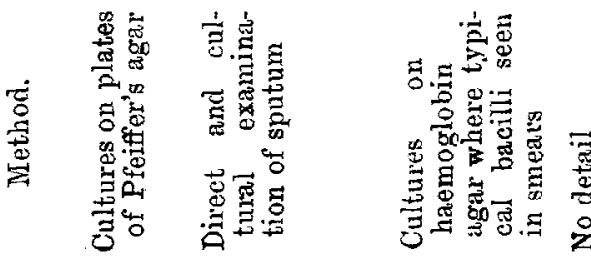

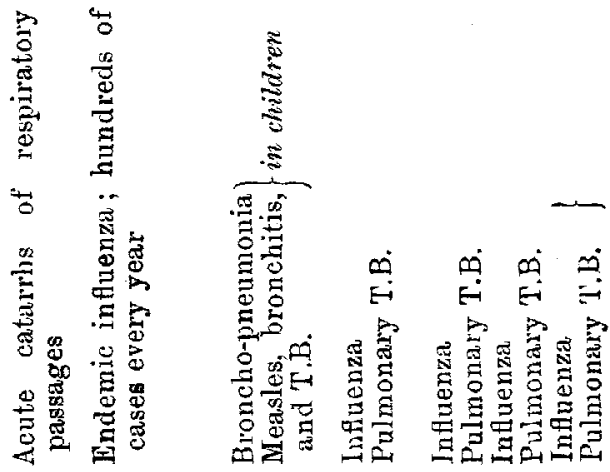

量

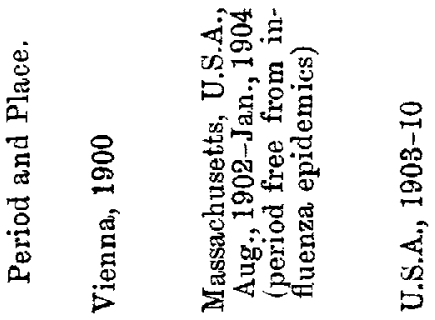

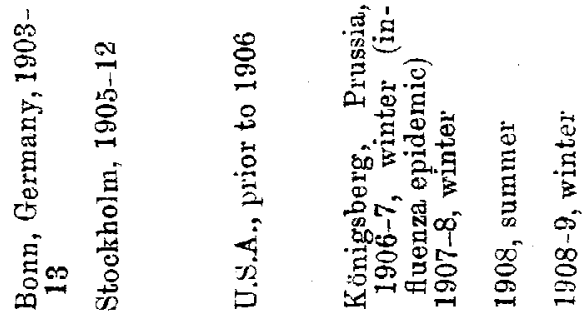

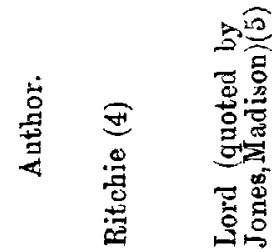

$\Xi$

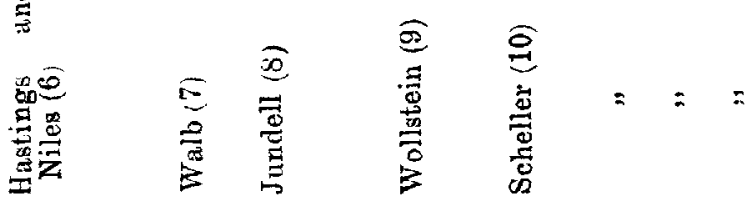




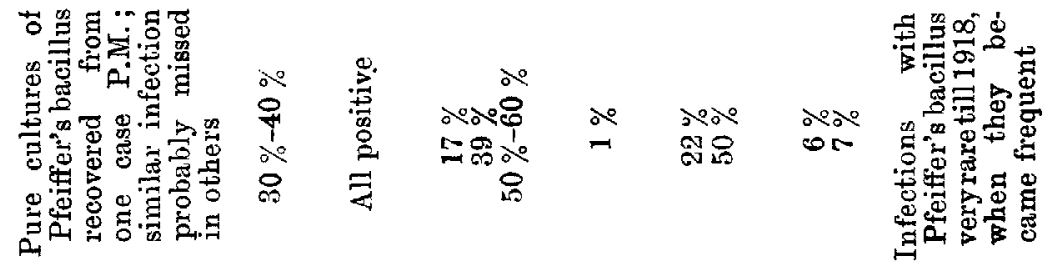

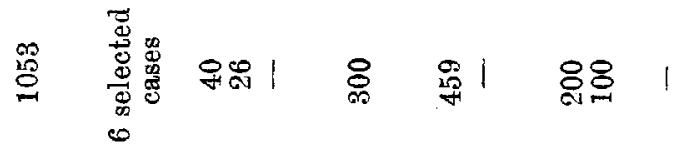
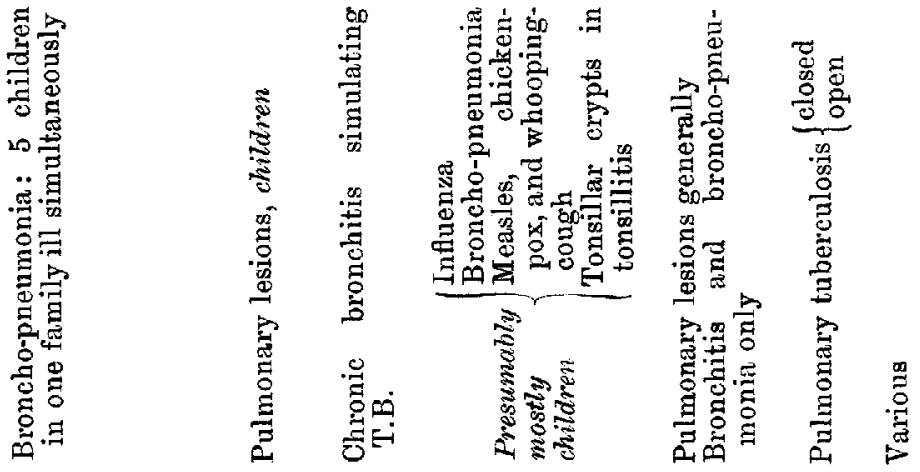

1

‡ี

节

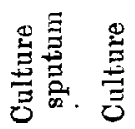

悉产
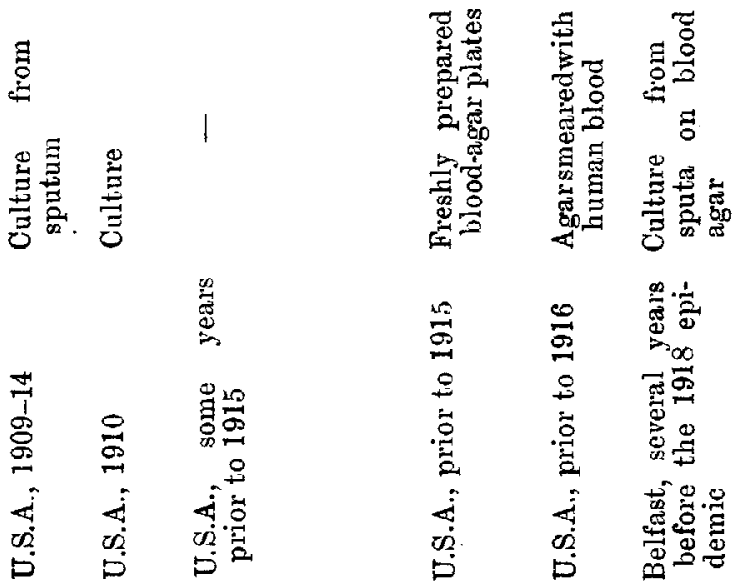

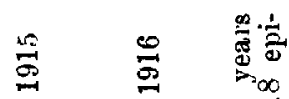

$\stackrel{\circ}{\circ}$

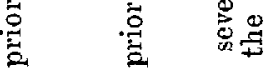

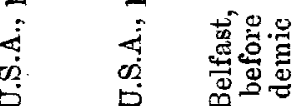

荧气

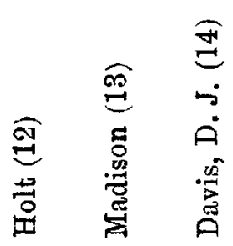

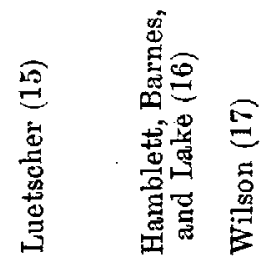


TABLE II. Observations between 1915 and the 1918 Epidemic.

\begin{tabular}{|c|c|c|c|c|c|}
\hline Author. & Period and Place. & Method. & $\begin{array}{l}\text { Condition of } \\
\text { Patients } \\
\text { examined. }\end{array}$ & $\begin{array}{l}\text { Number } \\
\text { exa- } \\
\text { mined. }\end{array}$ & $\begin{array}{l}\text { Percentage of In- } \\
\text { fections with } \\
\text { Pfeiffer's Bacillus. }\end{array}$ \\
\hline $\begin{array}{l}\text { Hunt and } \\
\text { Rankin (18) }\end{array}$ & Flanders, 1915 & $\begin{array}{l}\text { Naso - pharyngeal } \\
\text { swab on blood } \\
\text { agar }\end{array}$ & 'Trench' fever & 12 & Nil \\
\hline $\begin{array}{l}\text { Hübschmann } \\
\text { (19) }\end{array}$ & $\begin{array}{c}\text { Leipzig, } \\
\text { (spring) }\end{array}$ & $\begin{array}{l}\text { Culture on rab- } \\
\text { bit's blood agar }\end{array}$ & $\begin{array}{l}\text { P.M. observations } \\
\text { on patients dy- } \\
\text { ing with marked } \\
\text { bronchial in- } \\
\text { volvement dur- } \\
\text { ing localized in- } \\
\text { fluenza epidemic }\end{array}$ & 110 & $\begin{array}{l}28 \% \\
\text { (in smears appeared } \\
\text { to be present in } \\
63 \% \text { ) }\end{array}$ \\
\hline $\begin{array}{l}\text { Paltauf and } \\
\text { Petruschky } \\
(20)\end{array}$ & $\begin{array}{l}\text { Prisoners' camps } \\
\text { behind eastern } \\
\text { German front, } \\
1915\end{array}$ & 一 & $\begin{array}{l}\text { Bronchitis associ- } \\
\text { ated with typhns }\end{array}$ & - & $\begin{array}{l}\text { Pfeiffer's bacillus } \\
\text { found frequently }\end{array}$ \\
\hline Arneth (21) & $\begin{array}{l}\text { German troops, } \\
1915 \text { (spring) }\end{array}$ & $\begin{array}{l}\text { Examination of } \\
\text { sputum }\end{array}$ & $\begin{array}{l}\text { Atypical pneu- } \\
\text { monias }\end{array}$ & 28 & $58 \%$ \\
\hline $\begin{array}{l}\text { Williams and } \\
\text { Burdick (22) }\end{array}$ & $\begin{array}{c}\text { Denver, U.S.A., } \\
1915 \text { (autumn) }\end{array}$ & - & $\begin{array}{l}\text { Epidemic of 'in- } \\
\text { fluenza' }\end{array}$ & - & $\begin{array}{l}\text { Streptococcus con- } \\
\text { sidered to be the } \\
\text { cause }\end{array}$ \\
\hline Scholz (23) & $\underset{1915-16}{\text { German }}$ troops, & $\begin{array}{l}\text { Limited bacterio- } \\
\text { logical facilities }\end{array}$ & , & - & $\begin{array}{l}\text { Pfeiffer's bacillus only } \\
\text { found in cases with } \\
\text { broncho-pneumonia }\end{array}$ \\
\hline $\begin{array}{l}\text { Nammack } \\
(24)\end{array}$ & $\begin{array}{l}\text { New York? 1915- } \\
16 \text { (winter) }\end{array}$ & $\begin{array}{l}\text { Exudates mixed } \\
\text { with drop of } \\
\text { horse blood and } \\
\text { smeared on agar }\end{array}$ & $"$ & 50 & $\begin{array}{l}40 \% \\
\text { Pfeiffer's bacillus was } \\
\text { found more fre- } \\
\text { quently than any } \\
\text { other micro-or- } \\
\text { ganisms and six } \\
\text { times in pure culture }\end{array}$ \\
\hline Mathers (25) & $\begin{array}{l}\text { Uhicago, } 1915-16 \\
\text { (winter) }\end{array}$ & $\begin{array}{l}\text { Human blood-agar } \\
\text { plate }\end{array}$ & $\begin{array}{l}\text { Severe epidemic } \\
\text { of infections of } \\
\text { the upper re- } \\
\text { spiratory tract }\end{array}$ & 61 & $\begin{array}{l}\text { Pfeiffer's bacillus } \\
\text { found once }\end{array}$ \\
\hline $\begin{array}{l}\text { Moody and } \\
\text { Capps (26) }\end{array}$ & U.S.A., 1916 & Blood-agar plate & $\begin{array}{l}\text { Investigated same } \\
\text { epidemic as } \\
\text { Mathers }\end{array}$ & - & $6 \%-7 \%$ \\
\hline$\underset{(27)}{\text { Dnnn, J. S. }}$ & $\begin{array}{l}\text { North of France, } \\
1916-17\end{array}$ & -. & $\begin{array}{l}\text { P.M. observations } \\
\text { on cases of ne- } \\
\text { phritis with pul- } \\
\text { monary compli- } \\
\text { cations }\end{array}$ & - & $\begin{array}{l}\text { Pfeiffer-like bacilli } \\
\text { observed in a number } \\
\text { of cases }\end{array}$ \\
\hline $\begin{array}{l}\text { Ham mond, } \\
\text { Rolland,and } \\
\text { Shore (28) }\end{array}$ & $\begin{array}{l}\text { Base, North of } \\
\text { France, early } \\
\text { months, } 1917\end{array}$ & $\begin{array}{l}\text { Primary culture } \\
\text { on trypsin-legu- } \\
\text { min agar, second- } \\
\text { ary cultures on } \\
\text { blood agar }\end{array}$ & $\begin{array}{l}\text { Epidemic of puru- } \\
\text { lent bronchitis }\end{array}$ & 20 & $\begin{array}{l}50 \% \\
\text { (ins mears apparently } \\
\text { 90\%) }\end{array}$ \\
\hline $\begin{array}{l}\text { Abrahams, } \\
\text { Hallows, } \\
\text { Eyre, and } \\
\text { French (29) }\end{array}$ & $\begin{array}{l}\text { Aldershot com- } \\
\text { mand, early } \\
\text { months, } 1917\end{array}$ & Blood agar & As above & 8 & $\begin{array}{l}\text { (appeared } \\
\text { in all) }\end{array}$ \\
\hline $\begin{array}{l}\text { Robertson } \\
(30)\end{array}$ & $\begin{array}{l}\text { A. E. F., early } \\
\text { months, } 1918\end{array}$ & $\begin{array}{l}\text { Cultures from ac- } \\
\text { cessory sinuses of } \\
\text { head }\end{array}$ & Various & 15 & Found in all \\
\hline
\end{tabular}

